\title{
The Ongoing Challenge of HIV and AIDS to African Theology: A Review Article
}

\author{
Adriaan S. van Klinken \\ Centrum IIMO, Department of Religious Studies and Theology \\ Utrecht University, the Netherlands \\ email: a.s.vanklinken@uu.nl
}

\begin{abstract}
This article offers an extended review of some recent publications in the field of African theology and HIV and AIDS. Hence it critically examines the progress that is made in the engagement with and the reflection on issues related to the HIV epidemic by African theologians. The article notices the emergence of a new strand of Africa theology, a (liberation) theology of HIV and AIDS, which builds on and employs the classic strands of African liberation, inculturation, reconstruction and women's theology. Moreover, some challenging issues for the further African theological engagement with HIV and AIDS are identified.
\end{abstract}

Keywords: HIV and AIDS; African theology; liberation theology; African women’s theology.

\section{Introduction}

In 2008 this journal had a special issue entitled Church, Theology and People living with HIV and AIDS in Africa. Theological engagement with the challenges raised by the HIV epidemic was presented in this issue as one of the major recent developments in African theology. Martha Frederiks noticed that African theologians started relatively late to respond to issues of HIV and AIDS, but she observed a change from the 2000s when such a response became a theological trend. She even concluded that '[n]owadays the market is inundated with material on Aids and theology. ${ }^{1}$ In this review article I discuss some of the books that recently have "inundated the market" and that are part of the trend of African theologians dealing with issues related to the HIV epidemic:

E. Chitando, Troubled but not Destroyed, Geneva: WCC Publications 2009, 142 p., ISBN 9782-8254-1536-8.

E. Chitando and N.M. Hadebe (eds.), Compassionate Circles. African Women Theologians Facing HIV, Geneva: WCC Publications 2009.

R. Igo OSB, Windows into Hope. An Invitation to Faith in the Context of HIV and AIDS, Geneva: WCC Publications 2009, 251 p., ISBN 978-2-8254-1538-2.

M.W. Dube, The HIV \& AIDS Bible. Selected Essays, Scranton: University of Scranton Press, 2008, p. 208, ISBN 1-58966-114-1.

Three of the books are published by the World Council of Churches in the EHAIA series. The fourth title is written by Musa Dube, who has been working with EHAIA as its theological consultant. EHAIA is the Ecumenical HIV and AIDS Initiative in Africa, which is a wCC program that aims to strengthen the capacity of African churches to respond to the challenges raised by the HIV epidemic. One of the strategies is to stimulate theological reflection on HIV and AIDS, in order to educate students and church leaders, and to provide theological institutions and churches with materials.

Discussing these books in the present review, basically my question is what the publications add to the already existing body of literature. What is the progress made in the

\footnotetext{
${ }^{1}$ M.T. Frederiks, ‘HIV and Aids: Mapping Theological Responses in Africa’, Exchange 37/ 1 (2008), 22.
} 
theological engagement with HIV and AIDS? To answer this question I will critically review the publications and highlight some general observations in the conclusion.

\section{Troubled but not Destroyed}

With his book Troubled but not destroyed, Ezra Chitando does not aim to contribute to the African theological response to the HIV epidemic himself, but rather to survey and review this response. Educated in religious studies and currently a professor in the phenomenology of religion at the University of Zimbabwe, Chitando is not a theologian in the strict sense of the word. However, he also currently serves as the theological consultant of EHAIA, what indicates and explains his interest in theology and HIV and AIDS. Furthermore, Chitando realizes that the urgency of the HIV epidemic challenges religious studies to leave its stance of being academically 'neutral' and 'objective', and to engage with problems faced by society as well as with religious traditions that can provide resources for transformation. ${ }^{2}$ This constructive stance bridges the traditional distinction between religious studies and theology.

As a survey and review of African theology's response to HIV and AIDS, the book is a valuable resource and offers a critical assessment. The first chapter provides a general introduction to African theology from its historical development to its current major strands. Chitando distinguishes between inculturation theology, black and liberation theology, women's theology, and reconstruction theology (though he is aware that these categories are partly overlapping). In the subsequent chapters he discusses the response to the HIV epidemic provided from the respective strands. Generally, Chitando observes many challenges and opportunities for the various theologies to engage with HIV and AIDS. However, he evaluates that, except for African women's theology, African theology by and large is yet to provide an adequate response. Firstly, with regard to inculturation theology he emphasizes that the epidemic requires a far more critical engagement with 'African culture', as several cultural practices and beliefs are implicated with HIV and AIDS. At the same time, he notices a constructive task for this theology, being to uphold positive cultural values and to propose alternative rites and rituals in the time of HIV. Secondly, Chitando discusses African liberation theology and its Southern African counterpart black theology. He considers these theologies to be strategically placed to tackle HIV, because the epidemic is embedded in poverty and affects particularly black communities in the world. However, he observes that both strands of theology actually are in crisis and do hardly engage with HIV and AIDS, except for some younger scholars such as Musa Dube and Tinyiko Maluleke. The latter scholars are discussed in detail and are praised by Chitando, for example for their innovative work on 'liberating masculinities' in the era of HIV, and for their postcolonial critical analysis of globalization and HIV. Thirdly, with reference to reconstruction theology Chitando comments that this theology emerged in the 1990s when HIV was already a harsh reality, but that it has hardly begun to reflect on this challenge. This is explained by Chitando from the optimistic vision of a successful Africa that characterises reconstruction theology, with which HIV and AIDS obviously contradict. Fourthly, Chitando discusses African women's theology. According to his assessment, African women theologians are leading in the field of creative and constructive theological engagement with HIV and AIDS in Africa. Explaining this he points to the organizational structure of the Circle of Concerned African Women Theologians, to the Circle leadership that has planned and facilitated a focus on issues related to HIV and AIDS,

\footnotetext{
${ }^{2}$ Cf. E. Chitando, 'Equipped and ready to serve? Transforming theology and religious studies in Africa', http://www.oikoumene.org/fileadmin/files/wcc-main/documents/p5/ete/Ezra\%20Chitando\% 20\%20Equipped\%20and\%20ready\%20to\%20serve\%20-\%20Transforming\%20Theology\%20and\% 20Religious\%20Studies\%20in\%20Africa.pdf (accessed March 18, 2010).
} 
and to the collaboration of the Circle with other organizations and academic institutions. In Chitando's discussion of the Circle's response to HIV and AIDS, he especially highlights the work of Musa Dube who, as a woman theologian engaging in the paradigm of liberation theology, embodies the intersections between the various strands of African theology.

What is significant in Chitando's review is his observation that a great deal of African theology is hardly responding to issues of HIV and AIDS. It is a highly critical conclusion when he says: 'Although African theology prides itself as a contextual theology, its inability to tackle the HIV epidemic signals that this is more a claim than a fact.' (p. 63) Chitando disagrees with Frederiks' observation that the market is inundated with materials on theology and AIDS. Furthermore, in his opinion most publications are exploratory in character, and many issues are in great need of further analysis and reflection. Hence, he presents an agenda for further engagement with HIV and AIDS in African theology. At this point, it is regrettable that Chitando does not engage in theological reflection himself. He raises highly imperative theological questions, such as: 'Who is Christ to an African continent that is dying from AIDS and living with HIV?' and 'What does it mean to be "one body" when some members of that body are living with and affected by HIV?’ (p. 123). From his experience as a theological consultant with EHAIA, he surely will have some thoughts on these questions. ${ }^{3}$ Additionally, without denying the need for further theological reflection on these crucial questions, I think more work has been done than is suggested by Chitando. However, it is seldom done in a systematic and coherent way, and it takes a reconstructive approach to make the theological lines of thought that are present in many African theological publications on HIV and AIDS more explicit. ${ }^{4}$ It could be that Chitando's survey of African theology would have revealed more interesting insights when he had opted for such a method instead of the current comparative approach to the various strands of African theology. In this regard, it is also remarkable that some authors who are actively engaged in the theological response to HIV and AIDS are not included in the survey. The work of Isabel Phiri and Agbonkhianmeghe Orobator is referred to but hardly discussed; the work of South African scholars as Gerald West, Denise Ackermann and Beverley Haddad is not mentioned at all. Maybe the latter authors do not fit in the definition of African theology, although Chitando suggests using quite a broad definition of African theology.

Another issue with regard to the definition of African theology concerns the confessional background of the theologians under survey. Most authors represent Ecumenical-Protestant theology. This can be explained from the background that EHAIA, which is largely an Ecumenical-Protestant body itself, has actively supported African theological engagement with HIV and AIDS. Some Catholic authors are mentioned specifically, but how African Catholic theology as yet another strand of African theology responds to HIV and AIDS is not discussed. This gap is even more significant with regard to the theology of Pentecostal and Charismatic churches - which are often said to be the most vibrant parts of Christianity in Africa. Is it part of 'African theology'? How do these churches actually respond to HIV and AIDS both theologically and practically? Chitando mentions that HIV has led to 'grassroots ecumenism' (p. 124), but is there also collaboration and dialogue among theologians from the various African Christianities on issues of HIV and AIDS? I do not blame Chitando for not tackling these questions - I just point to a new area of research. In the present book, Chitando

\footnotetext{
${ }^{3}$ Chitando has shared his reflections in other publications, especially in the books Living with Hope. African Churches and HIV/AIDS 1 and Acting in Hope. African Churches and HIV/AIDS 2, Geneva: WCC Publications 2007. ${ }^{4}$ An example of such an approach is my own work on the use of the metaphor of the 'Body of Christ' in the publications of African theologians on HIV and AIDS. The theological lines of thought underlying the references to this metaphor directly relate to the questions raised by Chitando, 'Who is Christ?' and 'What does it mean to be one body?' See A.S. van Klinken, “"The Body of Christ has AIDS.” A Study on the Notion of the Body of Christ in African Theologies Responding to HIV and AIDs’, Missionalia 36/2-3 (2008), 319-336.
} 
has opted to focus on the major strands of that part of theology in Africa that explicitly names itself as "African theology". His underlying objective seems to be, to show that this theology does little to substantiate its claim of being relevant to the African context. Chitando presents this conclusion convincingly, and I hope his book will help to set the agenda for African theologies of inculturation, liberation and reconstruction in the next decade.

\section{Compassionate Circles}

The only strand of African theology evaluated positively by Chitando is African women's theology. From the early 2000s African women theologians, organized in the Circle of Concerned African Women Theologians, have demonstrated a deep commitment to respond to challenges raised by HIV and AIDS in Africa. This was informed by a major concern about the gendered face of the epidemic, as HIV and AIDS particularly affect, infect and impact upon women. ${ }^{5}$ Apart from two pan-African conferences addressing this topic (Addis Ababa 2002 and Yaoundé 2007) and many regional meetings of Circle chapters all over the continent, this has resulted in a significant number of publications. The book under discussion, Compassionate Circles, is the seventh English edited volume that has been published on HIV and AIDS. Additionally also some French books and a Portuguese volume have appeared. The present volume is the first one that is published with WCC Publications, showing the collaboration of the Circle with WCC/EHAIA. ${ }^{6}$ The editors are related to the Circle (Hadebe) and EHAIA (Chitando) respectively. First and for all, the productivity of the Circle is to be applauded, because the HIV epidemic continues to raise huge challenges to the people, communities, churches and societies in Africa and thus also to a theology that seeks to be contextually relevant. For that reason alone the present book is to be welcomed. Moreover, this volume should be welcomed, I think, because of two additional reasons.

First, some new issues are tackled in this book, and some issues are discussed in innovative ways. This shows the progress made in the theological engagement with HIV and AIDS. Let me give some examples. HIV is an ever-changing pandemic, what requires a sensitive attitude to new issues that arise. A case in point is Anti-Retroviral treatment, which is becoming increasingly available but also raises new challenges. These are addressed in the opening chapter by Eunice Kamaara. She discusses the difficulties women have in adhering to ART from a missiological perspective, suggesting some ways for churches to promote ART adherence among women. Other examples are the two articles dealing with children in the face of the epidemic - an issue that has not received much attention up to now. Lillian Siwila examines the vulnerability of girl orphans to sexual abuse in foster homes in Zambia. Hence she challenges communities and churches to take seriously the cultural and biblical demand to take care of orphans. Likewise, Angeline Madongonda and Ezra Chitando present the situation of children living with HIV in Zimbabwe as a challenge to the church, the school and the media, as these have to mitigate the impact of HIV in children's lives. To illustrate that some issues are discussed in a fresh way, I refer to the articles from Constance AmbasaShisanya and from Fulata Moyo. In earlier publications, African women theologians tended to be quite generalizing and negative in their accounts on culture in relation to gender and HIV.

\footnotetext{
${ }^{5}$ Cf. I.A. Phiri, 'African Women of Faith Speak Out in an HIV/AIDS Era', in: I.A. Phiri, B. Haddad and M. Masenya (eds.), African Women, HIV/AIDS and Faith Communities, Pietermaritzburg: Cluster Publications 2003, 3-22.

${ }^{6}$ The EHAIA general coordinator, Nyambura Njoroge, is a founding member of the Circle. The current Circle coordinator, Fulata Moyo, is the wCC program executive for women in church and society. The initiator of the Circle and the "founding mother" of African women’s theology, Mercy Amba Oduyoye, has been the wCC deputy general secretary. Clearly, there are and always have been close links between the movement of African women theologians and the World Council of Churches and recently its EHAIA program.
} 
However, rather than giving a general account on 'harmful African cultural practices', Ambasa-Shisanya focuses on one particular issue, widowhood, and on one specific region in Kenya. Such an ethnographic account provides valuable and more detailed insights on women, culture and HIV risks. Moyo deals with female initiation rites among specific ethnic groups in Malawi. Rather than giving a negative evaluation, she points out how these traditional rites can be used constructively for the sexual empowerment of women in the face of HIV. Because of the new issues they deal with, or the more nuanced approaches that are used, these articles make the book worth reading. Some of them, however, have a somewhat preliminary character, demonstrated in a broad scope and a less developed theoretical and theological framework. This calls for further research in the areas that are covered.

Secondly, this volume presents a highly significant development, being that the Circle has started to evaluate its engagement with HIV and AIDS by critically reviewing its publications in the area. In this way, the Circle aims to further improve its response to the epidemic. The volume includes two chapters of Musa Dube, a senior Circle member who has been in the forefront of theological engagement with HIV and AIDS (see below), where she undertakes such an assessment of African women theologians' responses to the epidemic. Though it is not clear why this is done in two partly overlapping chapters, Dube's evaluation is to be appreciated for its cross-cutting edge. She raises highly critical issues, such as the monolithic representation of the powerless 'African woman', the generalizing and stereotyping accounts on 'African culture' and 'African people', the negative depiction of African cultural and religious traditions, the sometimes stigmatizing and gender insensitive language that is used, the poor theoretical and theological frameworks that are employed, and the lack of methodologically sophisticated research. Hence, she makes some recommendations and proposes an agenda for further engagement of African women theologians with HIV and AIDS. Dube's evaluation presents a serious but constructive critique, and the Circle should be praised for giving space for such a critical review of its work. Hopefully this will bring the Circle's work on HIV and AIDS from a pioneering to a more sophisticated phase.

Clearly, it is time to make this step and to move to a next stage of theological engagement with HIV and AIDS. Unfortunately, the need for this is demonstrated by some of the articles in the volume under discussion. These can be used easily to illustrate many of the comments made by Dube. For example, the monolithic use of categories such as 'African women' and an unproblematized use of a massive concept like patriarchy in some articles, is not helpful to an analysis of the complex ways gender intersects with HIV and AIDS. Furthermore, questions can be raised concerning the theological character of the articles. First, the question arises what actually is theological in some of the papers except for being published in a book subtitled 'African women theologians facing HIV'. For example, the article from AmbasaShisanya does not deal with religion at all, nor does it discuss the anthropological findings on widowhood from a theological perspective. The paper of Chirongoma on Operation Murambatsvina and its impact on people living with HIV and AIDS in Zimbabwe, aims to discuss the sociological findings 'within the framework of Theology and Development' (p. 73), but the meaning and implications of this framework are hardly defined. There is only a call upon "the church" to address questions of social transformation for social justice. Similar 'call for ... theologies' that simply point to a problem and present it as a challenge to the church, can be found in the papers of Kamaara, Labeodan, Siwila, Madongonda and Chitando. In order for the response of theologians to the HIV epidemic to become a theological response, the tools and concepts of theological analysis, reflection and evaluation are to be further developed. This could be done by engaging critically with the dominant perspectives in African theology, such as inculturation, liberation, reconstruction and postcolonialism, and by further developing these paradigms or proposing alternative ones. Secondly, when papers explicitly deal with theological issues, this is sometimes done in a 
problematic way. The paper of Akintunde is a case in point. It deals with the crucial question of HIV as a punishment from God. Pointing to socio-cultural factors that facilitate HIV to spread and that especially increase the vulnerability of women, Akintunde argues that this perception is a misconception. However, by saying that some people living with HIV acquired the disease not as a result of sexual promiscuity, she suggests that other people actually did acquire the virus through promiscuity. This suggestion may not only reinforce stigmatization but also implies that for the latter group of people the disease actually can be considered a divine punishment. Indeed, Akintunde allows for this perception, since she says that it is 'not necessarily that God has decided to punish people for sexual perversion.' (p. 124) Though she seeks to oppose the perception of HIV as a divine punishment, she does not radically deconstruct it theologically, and hence she even reinforces it unintentionally. This underscores the need for more systematic theological work on the fundamental questions raised by HIV and AIDS.

To conclude, I hope that African women theologians will continue their groundbreaking work on HIV and AIDS of which this book is a demonstration again. At the same time, I hope that they will further develop the theoretical and methodological and especially the theological tools and frameworks of analysis and reflection, as this will benefit the quality and impact of their work.

\section{Window into Hope}

Above I raised the question for African Catholic theology and its response to HIV and AIDS. Surveying the African theological publications on HIV and AIDS, it appears that the majority of authors are Protestants. ${ }^{7}$ Therefore the book Windows into Hope of Catholic priest Robert Igo from Zimbabwe is to be welcomed. It is the third WCC publication on HIV and AIDS published in one year ${ }^{8}$, and as such it demonstrates EHAIA's considerable contribution to an ecumenical African theological engagement with the epidemic. Rather than being an academic book, it is intended as a 'resource to those in ministry, those preparing to minister and for Christian congregations' (p. 9). This reflects EHAIA's objective of publishing both scholarly and more practical theological materials, enabling theologians as well as churches and other organizations in society to reflect on, and respond to HIV and AIDS. In the present book, Igo who is a Benedictine priest involved in clinical counselling and therapy - shares his theological reflections informed by his ministry in Zimbabwe, a country severely affected by the epidemic. Faced with the stigmatization and discrimination of people living with HIV and AIDS, he underscores the need for a theology that does not associate HIV and AIDS with sexual sin and divine punishment, but which provides people with Christian hope and healing.

The basic assumption of Igo is that 'the God whom we are seeking is to be found in the very matrix of our lives' (p. 13). Exploring the urgent question how God, then, can be encountered in the context of HIV and AIDS, Igo presents an incarnational theology teaching that God is present and intricately involved in 'the stench and mess of people battling to live with a virus that violates their inherent gift of life' (p. 77). Surely this could be a meaningful theology, and it has a long tradition as is indicated by the biblical passages and theological authors Igo

\footnotetext{
${ }^{7}$ There are, however, some publications of African Catholic theologians dealing with issues of HIV and AIDS. For example, see B. Bujo and M. Czerny (eds.), AIDS in Africa. Theological Reflections, Nairobi: Paulines Publications 2007; A. Orobator, From Crisis to Kairos: The Mission of the Church in the Time of HIV/AIDS, Refugees, and Poverty, Nairobi: Paulines Publications 2005. See also the special issue on HIV and AIDS of the Catholic theological journal African Ecclesial Review 47:4/48:1 (2005-2006).

${ }^{8} \mathrm{~A}$ critical comment to the publisher concerns the inconsistent and inaccurate system of bibliographic references used in the footnotes of this book.
} 
refers to. However, one can raise the question whether it should not be the people living with HIV and AIDS themselves, who testify of an eventual divine presence in their lives, rather than the theological interpreter. Though Igo says that 'people and their stories [are] windows into God' (p. 69), unfortunately he does not explore his incarnational theology methodologically from an analysis of the many personal stories he must have heard. Furthermore, in light of the question for God in the midst of HIV and AIDS it is significant that Igo refers to the epidemic as 'a new holocaust, the holocaust of HIV and AIDS' (p. 73; see also p. 114ff). In my opinion this statement is highly problematic, since the HIV epidemic - despite of its huge proportions and devastating impact - is not a systematically and intentionally organized killing of millions of people. ${ }^{9}$ If according to Igo there is a relation between the holocaust and the HIV epidemic, he should be aware that the 'after Auschwitz-theology' generally states that it is extremely delicate (if not impossible) to make any theological sense out of this incomparable event in human history. ${ }^{10}$ Taking this seriously, it means that the question for God in the midst of HIV and AIDS remains (and has to remain) an open question which cannot be answered in general but only through people's personal testimonies of their experiences of divine presence (or absence) in this reality. Igo seems to acknowledge this himself as well, as he later on in the book speaks about the challenge for Christians in the HIV and AIDS era to live with unanswered questions (p. 109ff). At the same time, I realize that maybe this book is not to be read as a general theological account, but as Igo's personal testimony. Living in the reality of AIDS himself, the author surely is deeply affected by the epidemic, and it could be his own spiritual experience that 'suffering is an invitation for us to enter ever more deeply into human pain and tragedy, take the plunge and within it to find the mystery of God concealed.' (p. 116)

Apart from these deep theological questions raised by the HIV epidemic, Igo explores several other issues that are crucial, especially from a moral theological perspective. Where HIV and AIDS often are associated with sexual immorality and sin, he offers a balanced account that takes seriously both personal responsibility and the social structures that make it difficult for people to take responsibility, such as poverty, gender inequality, sexual abuse, international injustice, the lack of medical facilities etcetera (chapter 4). The critical issue of sexuality is discussed in chapter 6, where Igo argues that the HIV epidemic invites churches to adopt 'God's liberating view of human sexuality' (p. 129). Exploring this 'liberating view', he recapitulates John Paul II's theology of the body and reiterates Catholic moral teaching on sexuality. Unfortunately, he does not reflect on the meaning of this in relation to African traditional cultures or current African realities. A beautiful ideal is outlined, but what does it mean in the midst of poverty, HIV and AIDS, where sexuality has become a strategy of economic survival and a life-threatening power game surrounded by the shadow of disease and death? The high Catholic ideal of sexuality is upheld in chapter 7 as well, when Igo deals with the delicate issue of condoms. He argues that from the theology of the body not the reduction of infection rates, but the promotion of responsible sexual behaviour is a primary concern. In his opinion, condoms do not contribute to responsible behaviour (except in case of a married couple where one partner is HIV positive). Significantly, where Igo earlier in his book balances personal responsibility with social structures, in his discussion of condoms he only focuses on the responsibility of the individual. What would it mean for his assessment of condoms to take into account that people's agency is often limited and hindered by the social

\footnotetext{
${ }^{9}$ For a more elaborate and critical discussion, see J. Stiebert, 'The African “Holocaust”: What's in a Name?' in Missionalia 37:2 (2009), 192-209. For a more general critical discussion on the discourses on HIV and AIDS in Africa, see N. Botha, 'HIV/AIDS Discourse and the Quest for a Rebirth in Africa: A Theological Perspective' in A. Adogame, R. Gerloff and K. Hock (eds.), Christianity in Africa and the African Diaspora. The Appropriation of a Scattered Heritage, London and New York: Continuum 2008, 152-164.

${ }^{10}$ I am referring to theologians such as Jurgen Moltmann, Friedrich-Wilhelm Marquardt and Hans Janssen and their contribution to the rethinking of Christian theology after Auschwitz.
} 
realities they live in? Like the chapters on sexuality and condoms, chapter 8 , which discusses gender (in)equality and HIV, shows the difficulty for a Catholic author who wants to deal critically and constructively with these issues but at the same time wants to be in line with the theology of his church. Igo engages positively with the work of African women theologians who perceive gender inequalities as highly critical to the spread and impact of HIV and AIDS. ${ }^{11}$ He even realizes that 'gender inequality is not simply about prejudice against women' but rather 'is fundamentally about power and has taken the poisonous form of an ideology embodied in patriarchy' (p. 174). However, a few pages later he presents the theology of the body of John Paul II as a 'beautiful vision' of what it means to be created as male and female, and he does not show any critical awareness of the deeply rooted patriarchal ideology that, according to the analysis of women theologians, is present in dominant Christian theology and is manifested in the institution of the Roman-Catholic Church. ${ }^{12}$

Though not really ground-breaking and original, Igo's book could be helpful to educate and train those working in, or preparing for ministry in the church, and to stimulate them to theological reflection on issues raised by HIV and AIDS - and that is how the book is intended. In light of that objective, the last chapters are of interest: here attention is paid to the ministry to those dying of HIV and AIDS, to spiritual support of those infected and affected, and more generally to the prophetic witness Christians and churches are called to. It is through this practical pastoral reflection, rather than through an incisive theological argument, that the book may contribute to a theology and praxis of hope and healing.

\section{The HIV and AIDS Bible}

The name of Musa Dube has been mentioned in this review already several times. Chitando, in the book discussed above, praises her work and he presents her as 'a leading authority on theology and HIV in Africa.'13 Dube was Chitando's predecessor as EHAIA's theological consultant on HIV and AIDS in Africa, a position she held between 2002 and 2004. As such she has been in the forefront of getting church leaders and theologians engaged in the response to the challenges raised by the HIV epidemic. The book under discussion here, entitled The HIV and AIDS Bible. Selected Essays, presents ten papers written before and during this period. It is a pity that they have been published only recently (though some individual papers have already been published before). Most articles were written, as Dube says, 'within [the] context of mobilizing, equipping, and challenging African theological educators and church leaders continent wide' (p. 6-7), and each paper is 'a testimony to a particular time, moment, audience, and conversation in the history of the HIV \& AIDS struggle' (p. 10). From this background it is understandable that the various chapters of the book have some repetitions and are partly overlapping. One easily forgives this when reading the incisive and inspiring

\footnotetext{
${ }^{11}$ Theoretically, Igo's concepts are inaccurate. He critiques Musa Dube for confusing the concepts of gender and gender roles, but actually he is the one who causes conceptual confusion. He applies the concept of gender for what usually is called "sex": the biological difference between men and women; and he applies the concept of gender roles for what usually is just called "gender": the cultural and social constructs of masculinity and femininity (cf. p. 172). For a clear discussion on how the concept of gender is generally understood and is employed as an analytical category by African women theologians, see M.W. Dube, 'Culture, Gender and HIV/AIDS. Understanding and Acting on the Issues' in M.W. Dube (ed.), HIV/AIDS and the Curriculum. Methods of Integrating HIV/AIDS in Theological Programmes, Geneva: WCC Publications 2003, 86-88.

${ }^{12}$ For example, see R.N. Uchem, Overcoming Women's Subordination. An Igbo African and Christian Perspective: Envisioning an Inclusive Theology with Reference to Women, Enugu: Snaap Press 2001.

${ }^{13}$ E. Chitando, Troubled but Not Destroyed, Geneva: WCC Publications 2009, 5. See also E. Chitando and R. Gabaitse, 'Other Ways of being a Diviner-Healer: Musa W. Dube and the African Church's Response to HIV and AIDS' in E. Chitando (ed.), Mainstreaming HIV and AIDS in Theological Education: Experiences and Explorations, Geneva: WCC Publications 2008, 85-102.
} 
papers that reflect Dube's passionate engagement with, and vision for the subject of church, theology and HIV and AIDS. The book is an outstanding example of the powerful theology that can be born from activist-academic commitment to the problems faced by society and the quest for social transformation.

Significantly, Dube (just like Chitando) is not a theologian in the strict sense of the word. She is trained in biblical studies, with a well-received dissertation on postcolonial feminist biblical hermeneutics. ${ }^{14}$ In the first, autobiographical chapter of the book she recounts how she, as a career-planning scholar in New Testament studies, around the year 2000 became increasingly engaged in HIV and AIDS work, and finally left her university position to serve as EHAIA's theological consultant. Though being 'only a theologian by practice' (p. 38), Dube's hermeneutical skills as a biblical scholar have enabled her to develop a theological framework to understand and reflect upon HIV and AIDS. Feminist hermeneutics make her aware of the gendered face of the epidemic, and her familiarity with African women's theology helps to understand the intersections of gender, sexuality, culture, religion and HIV and AIDS. Liberation hermeneutics enable to understand the relation of HIV and AIDS to poverty and other kinds of structural injustice. Her critical postcolonial sensitivity helps to grasp the epidemic as embedded in neo-colonial politics and globalization. All this resounds in the statement, which is like a mantra through the book, that 'HIV and AIDS is an epidemic within other social epidemics', such as poverty, gender inequality, child abuse, racism, ethnic conflict, war, international injustice, and discrimination on the basis of sexual orientation. Theologically this implies that HIV and AIDS according to Dube is not just an issue of individual sexual morality, but first and for all is a social justice issue, because the choices of the individual are determined by their social locations and the structures in which these are embedded. Hence she calls for 'a prophetic theology of life that is able to address the individual and his or her social circumstances', 'a life-centered theology for our communities and for our world.' (p. 50)

The various hermeneutical lenses employed by Dube, are explored mainly in two chapters of the book: an essay on the methods of mainstreaming HIV and AIDS in biblical studies (chapter 3) and on African women's hermeneutics and HIV and AIDS (chapter 5). A powerful example of how the different hermeneutics and methods can be applied, is provided in chapter 4, where Dube presents a bible study on Mark 5: 21-43 about Jesus who heals the bleeding woman and calls the daughter of Jairus from death to life. Reading the story against the background of patriarchy and the Roman empire, and against today's context of international relations, gender inequalities and HIV and AIDS, Dube understands it as 'a story of resistance' in which Jesus appears as a liberator and healer who restores hope and life in the midst of despair and death. Hence, she uses the story both to encourage people and communities living with HIV and AIDS, and to call upon those who are not affected directly to engage in a quest for healing and justice. A creative re-telling of the same biblical narrative is provided in chapter 9. Here Dube takes the biblical story of the bleeding woman and draws it together with the colonial and neo-colonial history of the African continent, and especially of women on the continent, which she personifies in the fictive character of Princess Africa Izwelethu.

According to Dube, HIV and AIDS is not only embedded in other social epidemics, but has also given rise to yet a new epidemic, being the stigma related to HIV and AIDS. In light of the stigmatization and discrimination experienced by people living with HIV and AIDS in their (faith) communities, Dube underscores the need for a theology of compassion. She develops such a theology herself in chapter 7, entitled 'Towards an HIV \& AIDS Christology: Christ the compassionate healer and liberator'. It is one of the most incisive chapters of the book, which contributes to the ongoing quest in African theology for the meaning of Jesus Christ in light

\footnotetext{
${ }^{14}$ Cf. M.W. Dube, Postcolonial Feminist Interpretation of the Bible, St. Louis: Chalice Press 2000.
} 
of African realities. Dube not just presents Christ as the exemplary representation of Gods compassion but provides a more creative account. Re-reading Matthew 25: 31-46 she argues that Christ is represented in those living with HIV and AIDS. In their faces we see the face of the suffering Christ who 'bids us to see him crucified with all who are suffering from this disease, and also to seek to experience his resurrection in this context.' (p. 158) Drawing from the metaphor of the church as the body of Christ (1 Cor. 12) she argues that the church, just like Jesus Christ, is to identify with those living with HIV and AIDS. Paraphrasing the Pauline statement that 'when one members suffers, all members suffer together' (1 Cor. 12: 26), she states that the African church and the global church are 'to own up to the HIV \& AIDS epidemic as our pain, our problem.' (p. 152) Clearly, Christology and ecclesiology merge together into a powerful theology of compassion - with Dube emphasizing that compassion should not be understood as charity but stands for solidarity and justice, and requires liberation from all forms of injustice. This theology challenges churches and Christians, not only in Africa but worldwide, to consider themselves as part of the Body of Christ with AIDs. ${ }^{15}$

Dube's theology of HIV and AIDS is a prophetic theology that challenges the church and the world in view of the HIV epidemic ravaging many African societies. It addresses the social structures in which the epidemic is embedded and calls for justice; it addresses the stigma experienced by people living with HIV and AIDS and calls for solidarity. These prophetic calls make Dube's theology so powerful and imperative. However, a prophetic theology such as proposed by Dube has reverse sides as well. Firstly, the people living with HIV and AIDS themselves appear primarily as object rather than as subject. Their voices are not heard directly. It might be, that it are Dube's concerns about them, rather than their own concerns which are reflected in her theology. South African scholar Gerald West has argued that 'the key to the methodology of liberation theologies is the epistemological privileging of those who experience that particular marginalization. Those who know the lived reality of HIV/AIDS must become the primary interlocutors of theology. ${ }^{16}$ Surely Dube's work is informed by her relationships with people who live with HIV and AIDS and by their experiences ${ }^{17}$, and I look forward to publications in which she methodologically draws from this basis to develop a theology from people infected and affected by the epidemic. The need for such a theology is underscored by Chitando, who says: 'If theology places emphasis on experience (as it must), it is vital for theological reflections by people living with HIV to be accorded top priority in African theology. ${ }^{, 18}$ Secondly, though rhetorically powerful, the analytical categories used in Dube's prophetic theology are not always sophisticated. Take, for example, the category of gender. While Dube in other publications has critically pointed to the danger of a simplistic and generalizing analysis of gender and HIV and AIDS in the work of African women theologians $^{19}$, she yet runs this risk herself as well. Women generally are represented as powerless and vulnerable, and men as dominating, oppressive and risk-taking (cf. p. 51, 103-

\footnotetext{
${ }^{15}$ Cf. A.S. van Klinken, 'When the Body of Christ has AIDS. A Theological Metaphor for Global Solidarity in Light of HIV and AIDS', International Journal of Public Theology 4/4 (2010, forthcoming).

${ }^{16}$ G. West and B. Zengele, 'Reading Job 'Positively' in the Context of HIV/AIDS in South Africa', Concilium 4 (2004), 112.

${ }^{17}$ She even presents it as an ethical principle that 'all the plans and moral values that we propose for winning that struggle [against HIV \& AIDS] should be fully informed by listening to the experiences and stories of PLWHA [people living with HIV and AIDS] and all the vulnerable populations who find themselves living in the shadow of its threat. ... This listening should deeply move us and motivate us to identify with their pain, to seek change, and to act.' (M.W. Dube, The HIV \& AIDS Bible. Selected Essays, Scranton and London: University of Scranton Press 2008, 179-180.

${ }^{18}$ Chitando, Troubled but Not Destroyed, 125.

${ }^{19}$ See the two chapters in the book discussed above: M.W. Dube, 'HIV and AIDS Research and Writing in the Circle of African Concerned African Women Theologians 2002-2006' and 'In the Circle of Life: African Women Theologians' engagement with HIV and AIDS’ in E. Chitando and N. Hadebe, Compassionate Circles: African Women Theologians Facing HIV, Geneva: WCC Publications 2009.
} 
104, 149). While the concept of patriarchy has been strongly criticized in recent feminist and gender theory, Dube still employs it in a monolithic and unproblematized way (cf. p. 140). Though fully sympathizing with Dube's prophetic call for gender justice, I think that methodologically and analytically concepts like these are not always helpful to understand and investigate the complexities and ambiguities of gender constructions and their impact on HIV and AIDS.

\section{Conclusion}

The four books discussed in this article mark the end of the first decade of a substantial African theological engagement with HIV and AIDS. It is significant to observe that much of the issues that were addressed in the early publications, are still central in these recent publications: The need for theological engagement with HIV and AIDS is underlined; churches are challenged to become communities of solidarity and compassion; the perception of HIV and AIDS as a punishment from God among people, including pastors, is contested; the stigma surrounding HIV and AIDS, and the discrimination of people living with HIV and AIDS are critically addressed; the social structures in which the epidemic is embedded are highlighted. This is not to say that there is just repetition in the area of theology and HIV and AIDS, but that apparently it takes time for a theological framework to understand and deal with HIV and AIDS to emerge. Meanwhile, such a framework is crystallizing more and more. Significantly, where Chitando surveys the various classic strands of African theology for their response to HIV and AIDS, it is my perception that the HIV epidemic has given rise to yet a new strand, which could be simply named as an 'African theology of HIV and AIDS'. Characteristic of this theology is that it builds upon the paradigms and traditions of inculturation, liberation, black, reconstruction and women's theology but brings them together in creative ways in order to construct a theological approach that is able to deal with the major challenges put by HIV and AIDS. Basically this theology of HIV and AIDS is a new type of liberation theology, with its critical analysis of the social structures in which the epidemic is embedded, which are named as sinful and unjust. ${ }^{20}$ However, African women theologians have brought in a critical analysis of gender, what has resulted among others in the issue of masculinities being discussed currently by men and women theologians together. ${ }^{21}$ The theology of HIV and AIDS engages with inculturation when it seeks to employ creatively the resources from cultural traditions in order to fight HIV and AIDS and to provide healing to communities - though it tends to be far more critical to "culture" than inculturation theology is used to be. ${ }^{22}$ Further, it

\footnotetext{
${ }^{20}$ In 2001 Tinyiko Maluleke already suggested that 'a theology of HIV/AIDS is the face of a new "theology of liberation”. See T.S. Maluleke, The Challenge of HIV/AIDS for Theological Education in Africa. Towards an HIV/AIDS Sensitive Curriculum', Missionalia 29/2 (2001), 134.

${ }^{21}$ Cf. I.A. Phiri, 'Major Challenges for African Women Theologians in Theological Education (1989-2008)', International Review of Mission 98/1 (2009), 116. Among African scholars in religion and theology, Ezra Chitando is leading in the discussion of masculinities, religion and HIV and AIDS. For example, see E. Chitando and S. Chirongoma, 'Challenging Masculinities: Religious Studies, Men and HIV in Africa', Journal of Constructive Theology 14/1 (2008), 55-69; E. Chitando, 'Religious Ethics, HIV and AIDS and Masculinities in Southern Africa' in R. Nicolson (ed.), Persons in Community: African Ethics in a Global Culture, Scottsville: University of KwaZulu-Natal Press 2008, 45-63.

${ }^{22}$ See, for instance, J.M. Walligo, 'Inculturation and the HIV/AIDS Pandemic in the AMECEA Region', African Ecclesial Review 47-48/ 4-1 (2005-2006), 290-308; L. Magesa, 'Recognizing the Reality of African Religion in Tanzania' in J. F. Keenan (ed.), Catholic Ethicists on HIV/AIDS Prevention, New York and London: Continuum 2005, 76-83. Dube challenges African women theologians to engage, among others, in the paradigm of inculturation in their engagement with HIV and AIDS (see Dube, HIV and AIDS Research and Writing in the Circle of African Concerned African Women Theologians 2002-2006, 185 and 194-195). She refers to one of her publications as an example: M.W. Dube, 'Adinkra! Four Hearts Joined Together on Becoming Healer-Teachers
} 
engages with reconstruction theology as it seeks to rebuild African societies and to rehabilitate Africa's dignity in view of the reality of HIV and AIDS. ${ }^{23}$

Though a theological framework for HIV and AIDS has emerged, it is significant that precisely the deep theological issues are hardly discussed. These issues are mentioned by Dube when she says: 'The moment that we ask what God is saying to us through HIV \& AIDS, what God's will is concerning this disease, whether God loves us, whether God cares, and where God's healing is in this HIV \& AIDS era, then a theology of HIV \& AIDS has begun. ${ }^{24}$ Dube and most other scholars touch upon these questions in their publications but hardly explore them, especially when compared with the attention paid to social issues like gender, stigma, and poverty (though I realize, of course, that these social issues have a theological aspect as well). Of the four books discussed here, only Igo pays substantial attention to theological issues, but unfortunately not in a very incisive way. Although progress is made, Martha Frederiks' observation that 'theologically speaking the reflections are still in a preliminary stage' seems to be still valid. ${ }^{25}$ In light of this, it is particularly imperative for the theology of HIV and AIDS to become a theology of the people living with HIV and AIDS. Such a theology would not only include their questions and pains, but also their eventual experiences of the divine and the hope that keeps them alive in the midst of the struggle with the virus and its health, social and spiritual consequences.

A last observation with regard to the African theological publications on HIV and AIDS that have appeared thus far, concerns the theological background of the authors involved. As mentioned above, most authors are ecumenically oriented Protestant theologians. Furthermore, a number of scholars with a Catholic background have engaged with issues related to the epidemic. However, African Christianity is much broader than the traditions represented by these theologians. What theological response to HIV and AIDS does emerge from the Pentecostal and Charismatic traditions in African Christianity (which, noteworthy, have gained increased popularity in the same period the HIV epidemic has been ravaging the African continent)? The same question can be raised with regard to the African Instituted Churches. Though Pentecostal, Charismatic and African Instituted churches may not publish theological materials in the way Protestant and Roman-Catholic churches and theologians do, they certainly produce theology, for example in preaching, liturgy and church praxis and in the numerous bible colleges all over Africa. A crucial question for further research is how they respond theologically to HIV and AIDS and how this relates to the above outlined 'theology of HIV and AIDS' that emerges from the "mainstream" traditions of African Christianity.

To conclude, the HIV epidemic continues to challenge African theology. As HIV is a dynamic epidemic, constantly new issues arise that pose new challenges to churches and theologies in the context of HIV and AIDS. The books discussed in this review demonstrate that in the last decade a theological framework to understand and respond to the epidemic has emerged, mainly based on the paradigm of liberation theology and with women theologians in the forefront. However, it is also clear that theologically and methodologically the analysis of and reflection on issues related to the epidemic need to be advanced. One of the major challenges is broadening the horizon of theological engament with HIV and AIDS in Africa, as African theology and African Chrisitanity is much more diverse than what is represented by

of African Indigenous Religion/s in HIV \& AIDS Prevention' in I.A. Phiri and S. Nadar (eds.), African Women, Religion, and Health. Essays in Honor of Mercy Amba Ewudziwa Oduyoye, Maryknoll, New York: Orbis 2006, 131-156.

${ }^{23}$ Cf. Dube, The HIV \& AIDS Bible, 178-180; P. Kanyandago, 'Is God African? Theological Reflections on the AIDS Scourge' in N.W. Ndung'u and P. N. Mwaura (eds.), Challenges and Prospects of the Church in Africa. Theological Reflections of the 21st Century, Nairobi: Paulines 2005, 157-158.

${ }^{24}$ Dube, The HIV \& AIDS Bible, 47.

${ }^{25}$ Frederiks, HIV and Aids: Mapping Theological Responses in Africa, 22. 
the books under discussion. The epidemic will continue to challenge theology in African contexts in the years to come, and the publications discussed in this article open up new perspectives to engage these challenges critically, creatively and constructively.

Adriaan S. van Klinken (b. 1982) is a PhD Fellow at the Centre IIMO in the Department of Religious Studies and Theology, Utrecht University in the Netherlands. His academic interests are in the study of Christianity and theology in Africa, especially in relation to HIV and AIDS, and in the study of religion and gender, particularly masculinity. In his $\mathrm{PhD}$ project he investigates the involvement of African theologians and local churches (in Lusaka, Zambia) in the transformation of masculinities in the context of the HIV epidemic. 